Gut, 1978, 19, 85-90

\title{
Clinical, biochemical, and histological studies of osteomalacia, osteoporosis, and parathyroid function in chronic liver disease
}

\author{
R. G. LONG ${ }^{1}$, E. MEINHARD, R. K. SKINNER, Z. VARGHESE, M. R. WILlS, \\ AND SHEILA SHERLOCK ${ }^{2}$ \\ From the Departments of Medicine, Chemical Pathology, and Metabolic Unit, Royal Free Hospital, \\ London
}

SUMMARY Twenty of 32 patients with either chronic cholestatic or hepatocellular liver disease had bone pain or recent fractures. On bone biopsy five patients had normal bone, 15 had osteomalacia, five had osteoporosis, and seven had a combination of osteomalacia and osteoporosis. In the presence of osteoporosis, osteomalacia was minimal or absent. There was no biochemical, radiological, or histological evidence of excess parathyroid activity. No significant correlations were demonstrated between the plasma and urinary biochemical findings and the presence of either osteoporosis or osteomalacia and bone biopsy was essential for correct diagnosis. There was no statistical relationship between low serum 25-hydroxy vitamin D values and the presence of osteomalacia. Bone disease was not prevented by regular intramuscular vitamin $\mathrm{D}_{2}$, although biochemical changes were improved. Drugs such as corticosteroids and cholestyramine may be important aetiological factors in hepatic osteodystrophy.

Bone thinning and fractures are recognised complications of chronic cholestatic liver disease. Patients with either chronic cholestatis or hepatocellular liver disease may show histological evidence by bone biopsy of either osteomalacia or osteoporosis, and in some patients a combination of both (Atkinson et al., 1956). Calcium malabsorption has been demonstrated in primary biliary cirrhosis (PBC) and in hepatocellular disease; this has been attributed to decreased intestinal absorption of vitamin D (Keyhayoglou et al., 1968; Whelton et al., 1971). In these patients there are low serum 25hydroxy vitamin D (25-OHD) values (Long et al., 1976) which are not usually due to a failure of hepatic 25-hydroxylation (Skinner et al., 1977). Regular parenteral vitamin $\mathbf{D}_{2}$ supplements have previously been shown to improve ${ }^{47} \mathrm{Ca}$ absorption in PBC but not to prevent bone disease (Kehayoglou et al., 1968). Hypophosphataemia is a feature of chronic liver disease and this could be caused by an

'Present address: Department of Medicine, Hammersmith Hospital, Ducane Road, W12.

Address for reprint requests: Professor S. Sherlock, Department of Medicine, Royal Free Hospital, Pond Street, London, NW3 2QG.

Received for publication 30 June 1977 associated secondary hyperparathyroidism (Loeper et al., 1939; Rochman, 1976). The present study was undertaken to assess the incidence and type of metabolic bone disease in patients with either cholestatic or hepatocellular liver disease, to correlate the bone histology with the biochemical data, and to determine if the latter could predict bone histology.

\section{Methods}

Biochemical investigations were done after four-tofive days of stabilisation on a $20 \mathrm{mmol}(800 \mathrm{mg})$ per day calcium diet. Venous blood samples were collected without stasis after a 12 hour overnight fast. Plasma concentrations of calcium, phosphorus, magnesium, alkaline phosphatase activity, total protein, albumin, creatinine and ethanol-extractable hydroxyproline were estimated by standard methods (Varghese et al., 1973). The measured plasma calcium was corrected for variations in albumin concentration by the formula: adjusted calcium = (plasma calcium - albumin $(\mathrm{g} / \mathrm{dl})+4) \mathrm{mg} / \mathrm{dl}$ (Payne et al., 1973). This result was divided by 4 to obtain $\mathrm{mmol} / \mathrm{l}$. Alkaline phosphatase isoenzymes were estimated by heat inactivation (Whitby and Moss, 1975). Serum 25-hydroxy-vitamin D (25-OHD) 
Table 1 Clinical details $($ mean $\pm S D)$

\begin{tabular}{|c|c|c|c|}
\hline & Total & Cholestatic patients & Hepatocellular patients \\
\hline $\begin{array}{l}\text { Number } \\
\text { Age }(y r) \\
\text { Sex }(M: F) \\
\text { Duration of symptoms }(y r) \\
\text { Years serum total bilirubin }>\text { than } 51 \mu \mathrm{mol} / 1(3 \mathrm{mg} / 100 \mathrm{ml}) \\
\text { Bone pain or fractures }\end{array}$ & $\begin{array}{l}32 \\
53 \cdot 1 \pm 10 \cdot 7 \\
8: 24 \\
4 \cdot 7 \pm 3 \cdot 8 \\
1 \cdot 2 \pm 1 \cdot 4 \\
20\end{array}$ & $\begin{array}{l}25 \\
52 \cdot 9 \pm 11 \cdot 3 \\
5: 20 \\
5 \cdot 4 \pm 4 \cdot 0 \\
1 \cdot 4 \pm 1 \cdot 5 \\
17\end{array}$ & $\begin{array}{l}7 \\
54 \cdot 0 \pm 8 \cdot 7 \\
3: 4 \\
2 \cdot 1 \pm 0 \cdot 7 \\
0 \cdot 4 \pm 0 \cdot 8 \\
3\end{array}$ \\
\hline
\end{tabular}

concentration was measured by a modified competitive protein-binding technique (Long et al., 1976) and immunoreactive-parathyroid hormone (i-PTH) by radioimmunoassay (Wills et al., 1974). Two consecutive 24 hour urine collections were assayed for calcium, hydroxyproline and creatinine excretion and the mean of the two results used.

Vertical iliac crest bone biopsies were taken from all the patients under local anaesthesia with a Burkhardt drill. Specimens were processed by the method of Tripp and McKay (1972). Longitudinal sections were stained by standard haemotoxylin and eosin, Van Gieson, and reticulin techniques. After qualitative microscopy, quantatitive histological examination was undertaken using a rapid simple computerised technique (Meinhard et al., 1975). The microscope image of the trabecular portion of the section was projected ( $\times 100$ magnification) and traced directly onto computer data cards. An Optical Mark Reader fed the data into a minicomputer to provide tissue volume proportion ( $\mathrm{Vv} \%$ ) of osteoid, mineralised bone and total bone, and surface extent ( $\mathrm{Sv} \%$ ) of osteoblasts and osteoclasts. The normal range for increased osteoid tissue is less than $0.5 \% \mathrm{Vv}$ and for total bone is more than $20 \% \mathrm{Vv}$; values above and below these values respectively indicate osteomalacia and osteoporosis.

Statistical method was by calculating productmoment correlation coefficients and by Student's $t$ test. A multiple regression of increase in osteoid against total bone, plasma calcium, and phosphorus was also performed. Results are expressed as mean \pm SD.

PATIENTS STUdied (Table 1)

The 32 patients, 24 women and eight men, aged 21 to 64 years, had all been admitted to the Liver Unit at the Royal Free Hospital and diagnosis made on the basis of full investigation including liver biopsy. Twenty-five patients had cholestatic liver disease: PBC (20), secondary biliary cirrhosis (two), sclerosing cholangitis (one), postoperative biliary stricture (one), and childhood intrahepatic biliary atresia (one). Nineteen of the patients with PBC had clinical, biochemical, and histological evidence of late disease; in one the hepatic lesion was early. Seven patients had hepatocellular disease: alcoholic cirrhosis (three) alcoholic hepatitis without cirrhosis (three), and cryptogenic cirrhosis (one).

Duration of liver symptoms from onset to the time of bone biopsy was recorded together with the number of years that the serum total bilirubin had exceeded $51 \mu \mathrm{mol} / 1(3 \mathrm{mg} / 100 \mathrm{ml})$. The duration of symptoms for the patients with postoperative biliary disease was taken from the time of the first operation. The duration of liver symptoms ranged from four months to 18 years for the cholestatic patients. It was harder to assess duration of symptoms in the hepatocellular patients because the alcoholic patients tended to deny symptoms; it was probably about two to three years. In the cholestatic group the serum total bilirubin had exceeded $51 \mu \mathrm{mol} / 1(3 \mathrm{mg} / 100 \mathrm{ml})$ for $1.4 \pm 1.5$ years (eight of the 25 patients had never been jaundiced); in the hepatocellular group the mean years with a serum total bilirubin greater than $51 \mu \mathrm{mol} / 1$ was $0.4 \pm 0.8$ years.

Twenty of the patients complained of diffuse bone pain and eight of these had radiological evidence of recent fractures of hips, ribs, fibulae, or lumbar vertebrae; these had followed relatively minor trauma. Seventeen of the cholestatic patients (14 with PBC, two with secondary biliary cirrhosis, and one with sclerosing cholangitis) and three of the hepatocellular patients (two with alcoholic cirrhosis and one with alcoholic hepatitis) had either bone pain or fractures. Only one of the 32 patients (a case of PBC) showed radiological periosteal reactions on the lower end of the tibia. Pseudofractures were never detected.

Vitamin $\mathrm{D}_{2}$ (ergocalciferol) $100000 \mathrm{IU}$ in ethyl oleate intramuscular per month, had been given regularly to 16 of the cholestatic patients (PBC, 14; secondary biliary cirrhosis, one; and biliary atresia, one) with a mean duration of treatment of $2 \cdot 3 \pm 2 \cdot 1$ (range one to six years). At the time of investigation, 10 patients had received cholestyramine, three prednisolone, three frusemide, and one phenobarbitone for more than six months.

\section{Results}

BIOCHEMICAL FINDINGS (Table 2)

In eight patients (PBC, five; biliary atresia, one; alcoholic cirrhosis, one; and cryptogenic cirrhosis, 
Table 2 Biochemical results (mean $\pm S D$ )

\begin{tabular}{|c|c|c|c|c|}
\hline & Total & Cholestatic patients & $\begin{array}{l}\text { Hepatocellular } \\
\text { patients }\end{array}$ & Normal range \\
\hline \multirow{2}{*}{\multicolumn{5}{|c|}{$\begin{array}{l}\text { Number } \\
\text { Plasma: }\end{array}$}} \\
\hline & & & & \\
\hline $\begin{array}{l}\text { calcium mmol/1 } \\
(\mathbf{m g} / \mathrm{dl})\end{array}$ & $\begin{array}{l}2 \cdot 28 \pm 0 \cdot 18 \\
(9 \cdot 1 \pm 0 \cdot 7)\end{array}$ & $\begin{array}{l}2 \cdot 28 \pm 0 \cdot 18 \\
(9 \cdot 1 \pm 0.7)\end{array}$ & $\begin{array}{l}2.23 \pm 0.20 \\
(8.9 \pm 0.8)\end{array}$ & $\begin{array}{l}2 \cdot 13-2 \cdot 63 \\
(8 \cdot 5-10 \cdot 5)\end{array}$ \\
\hline $\begin{array}{l}\text { phosphorus mmol/l } \\
\text { (mg/dl) }\end{array}$ & $\begin{array}{l}1.03 \pm 0.16 \\
(3.2 \pm 0.5)\end{array}$ & $\begin{array}{l}1.00 \pm 0.16 \\
(3.1 \pm 0.5)\end{array}$ & $\begin{array}{l}1 \cdot 16 \pm 0.19 \\
(3.6 \pm 0.6)\end{array}$ & $\begin{array}{l}0 \cdot 87-1 \cdot 45 \\
(2 \cdot 7-4 \cdot 5)\end{array}$ \\
\hline magnesium mmol/1 & $0.86 \pm 0.10$ & $\begin{array}{l}0.90 \pm 0.08 \\
(2.2 \pm 0.2)\end{array}$ & $\begin{array}{l}0.78 \pm 0.25 \\
(1.9+0.6)\end{array}$ & $\begin{array}{l}0.74-0.99 \\
(1.8-2 \cdot 4)\end{array}$ \\
\hline total protein $\mathbf{g} / \mathbf{l}$ & $\begin{array}{l}79 \pm 10 \\
36+7\end{array}$ & $80 \pm 11$ & $\begin{array}{l}76 \pm 4 \\
36+5\end{array}$ & $\begin{array}{l}62-80 \\
35-50\end{array}$ \\
\hline $\begin{array}{l}\text { albumin } \mathbf{g} / \mathbf{1} \\
\text { alkaline phosphatase K.A. units/dl }\end{array}$ & $\begin{array}{l}36 \pm 7 \\
50 \pm 36\end{array}$ & $\begin{array}{l}37 \pm 7 \\
60 \pm 36\end{array}$ & $17 \pm 8$ & $3-13$ \\
\hline $\begin{array}{l}\text { hydroxy proline } \mu \mathrm{mol} / \mathrm{l} \\
(\mathrm{mg} / \mathrm{l})\end{array}$ & $\begin{array}{l}12.2 \pm 6.1^{*} \\
(1.6 \pm 0.8)\end{array}$ & $\begin{array}{l}12.2 \pm 6.1^{*} \\
(1.6 \pm 0.8)\end{array}$ & $\begin{array}{l}12 \cdot 2 \pm 7 \cdot 6^{*} \\
(1 \cdot 6 \pm 1 \cdot 0)\end{array}$ & $\begin{array}{l}6 \cdot 8-21 \cdot 3 \\
(0 \cdot 9-2 \cdot 8)\end{array}$ \\
\hline \multicolumn{5}{|l|}{ Serum } \\
\hline 25-OHD ng/ml & $11 \cdot 8 \pm 11.5$ & $13 \cdot 7 \pm 12 \cdot 3$ & $5.1 \pm 3.9$ & $9-44$ \\
\hline i-PTH ng/ml & $0.31 \pm 0.07$ & $0.32 \pm 0.07$ & $0.29 \pm 0.06$ & $0.25-0.95$ \\
\hline \multicolumn{5}{|l|}{$24 \mathrm{~h}$ urinary } \\
\hline calcium mmol & $2 \cdot 28 \pm 1 \cdot 33$ & $2 \cdot 45 \pm 1 \cdot 35$ & $1.55 \pm 0.98$ & $25-75$ \\
\hline (mg) & $(91 \pm 53)$ & $(98 \pm 54)$ & $(62 \pm 39)$ & $(100-300)$ \\
\hline $\begin{array}{l}\text { hydroxy proline } \mu \mathrm{mol} \\
(\mathrm{mg})\end{array}$ & $175 \pm 85^{*}$ & $180 \pm 82 *$ & $135 \pm 116^{*}$ & $<380$ \\
\hline Creatinine clearance $\mathrm{ml} / \mathrm{min}$ & $\begin{array}{c}(23 \cdot 0 \pm 11 \cdot 2) \\
76 \pm 34\end{array}$ & $\begin{array}{l}(23.7 \pm 10.8) \\
78 \pm 36\end{array}$ & $\begin{array}{l}(17 \cdot 7 \pm 15 \cdot 2) \\
68 \pm 21\end{array}$ & $\begin{array}{l}<50 \\
>80\end{array}$ \\
\hline
\end{tabular}

Results asterisked were from a total of only 21 patients, 18 being in the cholestatic group and three in the hepatocellular group. i-PT $H$ immunoreactive parathyroid hormone. 25-OHD: 25-hydroxy vitamin $D$.

one) plasma calcium values were less than $2 \cdot 13 \mathrm{mmol} / 1$ $(8.5 \mathrm{mg} / 100 \mathrm{ml})$ but, after correction for albumin levels, all values except in two PBC patients became normal. Low plasma phosphorus concentration stabilised to a low-normal range on a hospital diet. Only one patient (alcoholic hepatitis) had a greatly lowered plasma magnesium value of $0.33 \mathrm{mmol} / 1$ $(0.8 \mathrm{mg} / 100 \mathrm{ml})$. Plasma alkaline phosphatase activity was increased in both groups and was significantly higher in the cholestatic when compared with the hepatocellular group $(P<0.005)$. All the serum i-PTH and plasma hydroxyproline results were within the normal range. Serum i-PTH did not correlate with any of the other measured biochemical variables. Serum 25-OHD values were low in hepatocellular disease and in all 32 patients correlated with plasma calcium $(r 0.40, \mathrm{P}<0.05)$ but not with any of the other variables.

\section{HISTOLOGICAL FINDINGS}

Biopsies consisted of orderly lamellar bone. The iliac cortex varied from $0.1 \mathrm{~mm}$ to $3.0 \mathrm{~mm}$ in thickness. Cortices thinner than $1 \mathrm{~mm}$ were usual with osteoporotic biopsies. In two patients there was marked contrast between thick compact cortex and thin sparse underlying trabeculae.

Normal bone was found in PBC, (two); biliary atresia, (one); alcoholic hepatitis, (one); and cryptogenic cirrhosis (one).

Twenty-two patients (PBC, 15; secondary biliary cirrhosis, one; postoperative biliary stricture, one; sclerosing cholangitis, one; alcoholic cirrhosis, two, and alcoholic hepatitis, two) showed a slight to moderate osteomalacia $(0.5 \%$ volume proportion of osteoid or more) with an excess of osteoid with values up to $5 \% \mathrm{Vv} \%$. Both surface extent and maximal thickness increased with increasing osteoid volume.

Twelve of the patients (PBC, nine; secondary biliary cirrhosis, one; and alcoholic cirrhosis, two) showed volume proportion of total trabecular bone of less than $20 \%$ and were therefore defined as osteoporotic. In osteoporotic sections trabeculae were seen as a series of short narrow disconnected profiles.

Using a multiple regression of increase in osteoid against total bone, plasma calcium, and phosphorus, there was a significant correlation between osteoid volume and total bone volume $(P<0.05)$. All biopsies with an osteoid volume of greater than $1.5 \%$ showed a total bone of greater than $20 \% \mathrm{Vv}$. (Figure). Osteomalacia was therefore minimal in the presence of osteoporosis.

There was no evidence of increased osteoblasts on mineralised or osteoid covered surfaces. An occasional small osteoclast was seen in shallow excavations (one lamella deep) but tunnelling resorption was not observed. Histological evidence of excess parathyroid activity on bone (osteitis fibrosa) was entirely lacking.

EFFECT OF VITAMIN-D TREATMENT (Table 3) The patients treated with regular vitamin $D_{2}$ had been jaundiced significantly longer than the untreated patients $(P<0.05)$ and also had had more prolonged liver symptoms $(P<0 \cdot 10)$. The serum $25-$ OHD was higher in the treated patients $(P<0.02)$ 
Table 3 Biochemical results (mean $\pm S D$ ) in group of patients with cholestatic liver disease when subdivided into those who had or had not received regular parenteral vitamin $D_{2}$ therapy

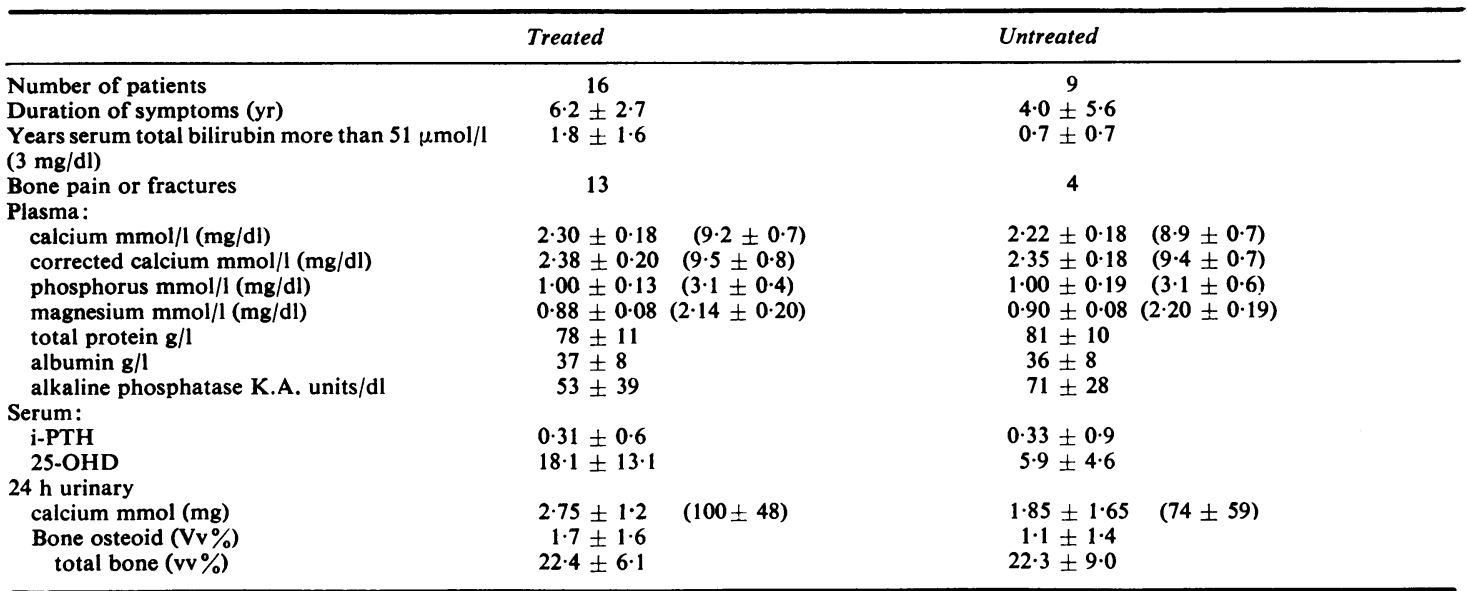

i-PTH: immunoreactive parathyroid hormone. 25-OHD: 25-hydroxy vitamin D.

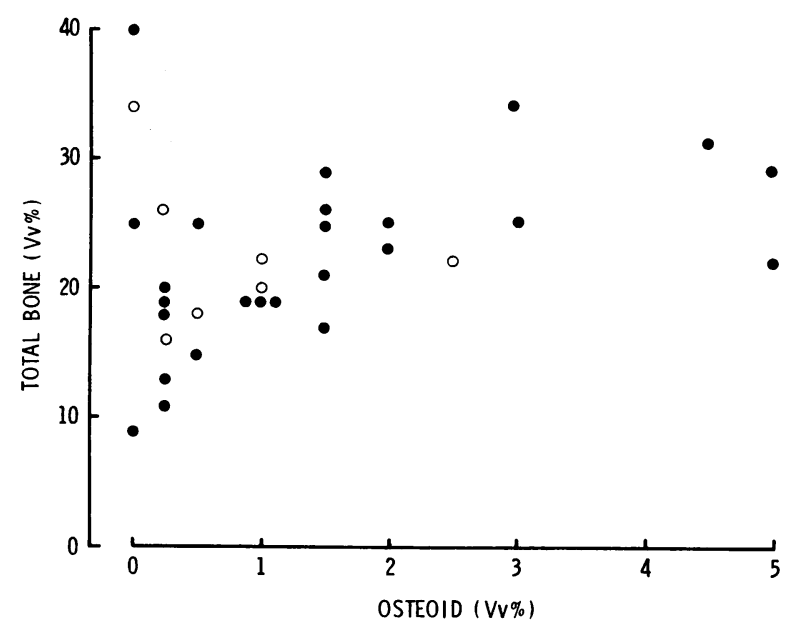

Figure Graph of total bone $(V v \%)$ and osteoid tissue $(V v \%)$ in 32 patients. Values of less than $20 \%$ Vv total bone indicate osteoporosis and $0.5 \% \mathrm{Vv}$ or more osteoid indicate osteomalacia. $\bigcirc$ : hepatocellular disease;

- : cholestatic liver disease. Multiple regression with calcium and phosphorus, $\mathrm{r} 0.40, \mathrm{P}<0.05$.

and this was associated with higher 24 hour urinary calcium values $(P<0 \cdot 10)$ and plasma corrected calcium values $(P<0 \cdot 30)$. Despite these biochemical changes, increased osteoid tissue was if anything more marked in the treated patients.
CORRELATIONS BETWEEN HISTOLOGICAL, CLINICAL, AND BIOCHEMICAL DATA

There was no statistically significant correlation between any of the clinical data and the observed osteoid tissue or total bone values. Of the 22 patients with osteomalacia, 12 had bone pain and five of these had had recent fractures; nine of the 12 osteoporotic patients had bone pain and four of these had

- had recent fractures. The amount of osteoid tissue tended to increase with the number of years that the total bilirubin had been more than $51 \mu \mathrm{mol} / 1(3 \mathrm{mg} /$ $100 \mathrm{ml})(r 0 \cdot 23)$ but less so with the duration of liver symptoms ( $r$ 0.04); these correlations were less for total bone.

Eleven of the 12 osteoporotic patients were over 45 years of age. Symptomatic osteoporosis was found in all three PBC patients who had received corticosteroid therapy; one of these had $1 \%$ volume increase in osteoid. Of the 10 patients (PBC, nine; biliary atresia, one) on cholestyramine, two had normal bone, six had varying degrees of osteomalacia, one had osteoporosis, and one had slight osteomalacia with osteoporosis. All the patients (PBC, three) receiving frusemide had osteomalacia; one also had osteoporosis. The patient (PBC) receiving phenobarbitone had osteomalacia.

There were no significant correlations between the plasma, serum, and urinary biochemical findings and the osteoid tissue or total bone values. There was a poor correlation $(r-0 \cdot 10)$ between serum 25-OHD and increases in osteoid tissue. In particular, increased osteoid tissue did not correlate with an increased percentage of bone alkaline phosphatase isoenzyme; the increased total alkaline phosphatase 
activity in these patients was mainly caused by increased liver isoenzyme. Serum 25-OHD was $15.1 \pm 9.7 \mathrm{ng} / \mathrm{ml}$ in eight patients (PBC, six; secondary biliary cirrhosis, one; and biliary atresia, one) treated with vitamin $\mathrm{D}$ and cholestyramine and was not significantly different from the value of $21.2 \pm 15.9 \mathrm{ng} / \mathrm{ml}$ in eight patients (PBC, eight) treated with vitamin $\mathrm{D}$ and no cholestyramine.

\section{Discussion}

A high incidence of both osteomalacia and osteoporosis was found with chronic cholestatic and with alcoholic liver disease. We are unaware of previous reports of osteomalacia in alcoholic liver disease. Symptomatic bone disease seems rare in nonalcoholic chronic hepatocellular disease (Paterson and Losowsky, 1967). The morbidity associated with both histological bone lesions was shown by the high incidence of bone pain and fractures. Osteomalacia was minimal when osteoporosis was present but the nature of the bony lesion could not be predicted by clinical and biochemical techniques. Radiology was also unreliable. The treatment for osteoporosis and osteomalacia is different and a bone biopsy is essential for accurate diagnosis.

The osteomalacia and osteoporosis were often associated with normal plasma and urinary biochemistry, especially after plasma calcium had been corrected for plasma albumin levels. However, vitamin D (Thompson et al., 1966) and calcium absorption are abnormal in biliary disease and protein synthesis is reduced in cirrhosis. Plasma values do not necessarily reflect the whole body or bone status. Estimations of whole body and bone calcium, phosphorus, magnesium, and vitamin $D$ could be helpful.

Although some of the biochemical findings, particularly serum 25-OHD, improved after parenteral vitamin $D_{2}$ therapy, bone disease was neither prevented nor cured. These observations are of importance in the aetiology of hepatic osteodystrophy. In the patients treated with vitamin $\mathrm{D}_{2}$ the predominant circulating form of serum 25-OHD is probably vitamin $D_{2}$ rather than $D_{3}$. The findings in the patients studied here are of considerable interest when compared with the studies of Wagonfeld et al. (1976) who showed improvement or stabilisation of bone mineral content with oral 25 -hydroxy vitamin $D_{3}$. Although vitamin $\mathbf{D}_{2}$ is said to be as effective as $D_{3}$ in treating osteomalacia in man (Omdahl and DeLuca, 1973), this may not be so. Other possible reasons for therapeutic resistance include a failure of synthesis of dihydroxy vitamin D metabolites and end-organ unresponsiveness.

In the presence of osteomalacia, hypophosphatae- mia and creatinine clearance values of less than 70 $\mathrm{ml} / \mathrm{min}$ in 13 patients, one would have expected raised levels of i-PTH. Radiological osteitis fibrosa has not been reported in chronic liver disease and was not seen in this series. The normal serum i-PTH and plasma and urinary hydroxy proline support normal parathyroid function; moreover, bone histology did not show the changes of hyperparathyroidism.

Diet and drugs may well be important in the development of metabolic bone disease. Alcoholics usually have a poor diet (Leevy et al., 1970). Ethanol can cause osteoporosis and also has a direct effect on the gut inhibiting calcium absorption (Krawitt, 1975). Poor nutrition, including a lack of vitamin C, is a feature of other liver disease (Beattie and Sherlock, 1976). Low salts diets often contain a low daily calcium allowance. Cholestyramine has been shown to cause vitamin $D$ malabsorption in rats (Thompson and Thompson, 1969) and relate to osteomalacia in man (Heaton et al., 1972; Compston and Thompson, 1977). Frusemide and the thiazide diuretics increase urinary calcium excretion: in osteomalacia spironolactone may be superior. Phenobarbitone, now used as a choleretic, may cause osteomalacia by hepatic enzyme induction (Bowden, 1974). This study shows the osteoporotic effect of corticosteroids in PBC and as they have not been shown to be of therapeutic value their use appears to be contraindicated.

No single aetiological factor has emerged from this study to explain the osteomalacia and osteoporosis of liver disease. As in renal osteodystrophy the aetiology is likely to be multifactorial (Wills, 1971). In osteomalacia adequate parenteral vitamin $\mathrm{D}$ and oral calcium phosphorus and magnesium should be given to correct blood values to normal and, if possible, frusemide, cholestyramine, alcohol, and phenobarbitone should be avoided. In osteoporosis a diet containing high vitamin $\mathrm{C}$ and protein with the avoidance of corticosteroids and alcohol is recommended; mobilisation should be encouraged. Clinical trials of these measures together with bone biopsy data are needed.

We thank David Clayton and David Wadbrook for help with statistical analysis and John Difford for preparing the bone histology. We wish to thank Mr A. Chester Beatty for financial support. We also thank Dr Joan $M$. Zanelli for advice and the National Institute of Biological Standards and Control for providing reagents for radioimmunoassay of i-PTH. E.M. was in receipt of a grant from the Medical Research Council. 


\section{References}

Atkinson, M., Nordin, B. E. C., and Sherlock, S. (1956). Malabsorption and bone disease in prolonged obstructive jaundice. Quarterly Journal of Medicine, 25, 299-312.

Beattie, A. D., and Sherlock, S. (1976). Ascorbic acid deficiency in liver disease. Gut, 17, 571-575.

Bowden, A. N. (1974). Anticonvulsants and calcium metabolism. Developmental Medicine and Child Neurology, 16, 214-216.

Compston, J. E., and Thompson, R. P. H. (1977). Intestinal absorption of 25-hydroxyvitamin $\mathrm{D}$ and osteomalacia in primary biliary cirrhosis. Lancet, 1, 721-724.

Heaton, K. W., Lever, J. V., and Barnard, D. (1972). Osteomalacia associated with cholestyramine therapy for postileectomy diarrhoea. Gastroenterology, 62, 642-646.

Kehayoglou, A. K., Holdsworth, C. D., Agnew, J. E., Whelton, M. J., and Sherlock, S. (1968). Bone disease and calcium absorption in primary biliary cirrhosis with special reference to vitamin-D therapy. Lancet, 1, 715-719.

Krawitt, E. L. (1975). Effect of ethanol ingestion on duodenal calcium transport. Journal of Laboratory and Clinical Medicine, 85, 665-671.

Leevy, C. M., Thompson, A., and Baker, H. (1970). Vitamins and liver injury. American Journal of Clinical Nutrition, 23, 493-499.

Loeper, M., Lemaire, A., and Lesobre, R. (1939). Spondylomalacie dans la cirrhose bilaire. Archives des Maladies de l'Appareil Digestif et des Maladies de la Nutrition, 29, 577 587.

Long, R. G., Skinner, R. K., Wills, M. R., and Sherlock, S. (1976). Serum-25-hydroxy-vitamin-D in untreated parenchymal and cholestatic liver disease. Lancet, 2, 650-562.

Meinhard, E. A., Wadbrook, D. G., Ring, C., Varghese Z., Tatler, G. L. V., Fairney, A., Wills, M. R., and Moorhead, J. F. (1975). Computer card morphometry in uraemic bone disease. In Vitamin $D$ and Problems Related to Uremic Bone Disease, pp. 549-552. Edited by A. W. Norman, K. Schaefer, H. G. Grigoleit, D. von Herrath and E. Ritz. Walter de Gruyter: Berlin.

Omdahl, J. L., and DeLuca, H. F. (1973). Regulation of vitamin D metabolism and function. Physiological Reviews, 53, 327-372.

Paterson, C. R., and Losowsky, M. S. (1967). The bones in chronic liver disease. Scandinavian Journal of Gastro- enterology, 2, 293-300.

Payne, R. B., Little, A. J., Williams, R. B., and Milner, J. R. (1973). Interpretation of serum calcium in patients with abnormal serum proteins. British Medical Journal, 4, 643646.

Rochman, J. (1976). Exaggerated hypophosphataemia and diuresis following extracellular volume expansion (ECVE) in patients with primary biliary cirrhosis. In Abstracts of Second International Workshop on Phosphate, p. 15. Heidelberg.

Skinner, R. K., Long, R. G., Sherlock, S., and Wills, M. R. (1977). 25-hydroxylation of vitamin $\mathrm{D}$ in primary biliary cirrhosis. Lancet, 1, 720-721.

Thompson, G. R., Lewis, B., and Booth, C. C. (1966). Absorption of vitamin $\mathrm{D}^{3}-{ }^{3} \mathrm{H}$ in control subjects and patients with intestinal malabsorption. Journal of Clinical Investigations, 45, 94-102.

Thompson, W. G., and Thompson, G. R. (1969). Effect of cholestyramine on the absorption of vitamin D3 and calcium. Gut, 10, 717-722.

Tripp, E. J., and MacKay, E. H. (1972). Silver staining of bone prior to decalcification for quantitative determination of osteoid in sections. Stain Technology, 47, 129-136.

Varghese, Z., Moorhead, J. F., Tatler, G. L. V., Baillod, R. A., and Wills, M. R. (1973). Plasma hydroxyproline in renal osteodystrophy. Proceedings of the European Dialysis and Transplant Association, 10, 187-196.

Wagonfeld, J. B., Nemchausky, B. A., Bolt, M., Horst, J. V., Boyer, J. L., and Rosenberg, I. H. (1976). Comparison of vitamin-D and 25-hydroxy-vitamin-D in the therapy of primary biliary cirrhosis. Lancet, 2, 391-394.

Whelton, M. J., Kehayoglou, A. K., Agnew, J. E., Turnberg, L. A., and Sherlock, S. (1971). "Calcium absorption in parenchymatous and biliary liver disease. Gut, 12, 978-983.

Whitby, L. G., and Moss, D. W. (1975). Analysis of heat inactivation curves of alkaline phosphatase isoenzymes in serum. Clinica Chimica Acta, 59, 361-367.

Wills, M. R. (1971). The Biochemical Consequences of Chronic Renal Failure, p. 840. Harvey, Miller and Metcalf: Aylesbury.

Wills, M. R., Fairney, A., Varghese, Z., Tatler, G. L. V., Baillod, R. A., and Moorhead, J. F. (1974). Serum parathyroid hormone concentration in chronic renal failure patients on maintenance haemodialysis. Clinica Chimica Acta, 57, 83-89. 